\title{
Comparison of Monoclonal Antibodies and Polymerase Chain Reaction Assays for the Typing of Isolates Belonging to the $D$ and M Serotypes of Plum Pox Potyvirus
}

\author{
T. Candresse, M. Cambra, S. Dallot, M. Lanneau, M. Asensio, M. T. Gorris, \\ F. Revers, G. Macquaire, A. Olmos, D. Boscia, J. B. Quiot, and J. Dunez
}

First, fourth, seventh, eighth, and twelfth authors: Station de Pathologie Végétale, INRA, BP81, 33883 Villenave d'Ornon Cedex, France; second, fifth, sixth, and ninth authors: Departamento de Protección Vegetal y Biotecnología, Instituto Valenciano de Investigaciones Agrarias (IVIA), Apartado oficial, 46113 Moncada, Valencia, Spain; third and eleventh authors: Pathologie Végétale, INRA, 2 Place Viala, 34060 Montpellier Cedex 01, France; and tenth author: Dipartimento di Protezione delle Piante, Universita degli Studi and Centro di Studio del CNR sui Virus e Virosi delle Colture Mediteranee, Via Amendola 165/A, 70126 Bari, Italy. Accepted for publication 17 November 1997.

\begin{abstract}
Candresse, T., Cambra, M., Dallot, S., Lanneau, M., Asensio, M., Gorris, M. T., Revers, F., Macquaire, G., Olmos, A., Boscia, D., Quiot, J. B., and Dunez, J. 1998. Comparison of monoclonal antibodies and polymerase chain reaction assays for the typing of isolates belonging to the $\mathrm{D}$ and $\mathrm{M}$ serotypes of plum pox potyvirus. Phytopathology 88:198-204.

Plum pox potyvirus (PPV) isolates may be divided into four groups separated by serological, molecular, and epidemiological differences. Monoclonal antibodies specific for the two major groups of isolates, represented by the $\mathrm{D}$ and $\mathrm{M}$ serotypes of the virus, have been obtained. Polymerase chain reaction (PCR)-based assays allowing the direct detection and differentiation of PPV isolates have also been developed. We now report on a large-scale comparison of these two typing approaches. The results obtained show an overall excellent correlation between the results obtained in indirect double-antibody sandwich enzyme-linked

immunosorbent assay using PPV-D- and PPV-M-specific monoclonal antibodies and those derived from either specific PCR assays or restriction fragment length polymorphism analysis of PCR fragments. Without exception, all isolates reacting positively with the PPV-M-specific monoclonal antibody were found to belong to the M serotype using the PCRbased assays, while 51 out of 53 isolates recognized by the D-specific monoclonal antibodies belonged to the D serotype according to the PCR typing results. However, failure to react with a specific monoclonal antibody did not prove as effective a predictor of the serotype of the isolate analyzed. In a few cases, the results obtained with the various techniques diverged, indicating low level variability of the epitopes recognized by the serotype-specific monoclonal antibodies. Isolates belonging to the two minor groups of PPV (El Amar and Cherry) also gave divergent results, indicating that the current typing assays are not suited for the analysis of such isolates.
\end{abstract}

Plum pox potyvirus (PPV), the causal agent of the sharka disease, is considered the most detrimental viral pathogen of stone fruit crops in Europe and around the Mediterranean Basin (10,24). The impact of the disease stems from both the severity of the damage caused to susceptible crops and the quarantine status of PPV, making it a strong limiting factor on germ plasm and propagation material movement. PPV is present in most western, central, and eastern European countries. Absent until recently from the Americas, it was recently detected in Chile, with a potential to spread to other stone fruit tree-growing regions in this part of the world (23). Sanitary selection, eradication of affected trees, and quarantine procedures currently are the keys to fighting the sharka disease in many countries in which the virus has not yet reached endemic status (6). To sustain these efforts, very effective methods to detect PPV have been developed over the years. Starting from woody indexing in GF305 peach seedlings and polyclonal antibody-based enzyme-linked immunosorbent assays (ELISA), the range of available detection techniques now includes monoclonal antibody (MAb)-based assays (4), molecular hybridization (25), and polymerase chain reaction (PCR)-based assays $(12,14$, 19,26,28).

Early efforts at differentiating PPV isolates were not successful. However, using polyclonal antisera, Kerlan and Dunez (11) dem-

Corresponding author: T. Candresse; E-mail address: tc@bordeaux.inra.fr

Publication no. P-1998-0102-01R

(c) 1998 The American Phytopathological Society onstrated the existence of two major serotypes of PPV, serotype D (Dideron) and serotype M (Marcus), on the basis of limited serological cross-reactivities. More recently, MAbs showing serotypespecific reactivities have been obtained for both the D (4) and M (2) serotypes. Following a different route of investigation, sequence analysis of PCR fragments corresponding to the C-terminal part of the PPV coat protein gene has allowed the identification of a molecular polymorphism correlated with the serotype of the PPV isolates $(8,9)$. Initial results have indicated that an RsaI restriction fragment length polymorphism (RFLP) located in this region could be used, following PCR amplification, to discriminate between the D and $M$ serotypes of PPV $(3,28)$. More recently, a cluster of noncoding, third-base mutations on five consecutive codons located around the RsaI RFLP site was found to show an excellent correlation with the viral serotype (9). This observation was used as the basis for direct PCR typing of isolates belonging to the $\mathrm{D}$ and $\mathrm{M}$ serotypes of PPV (8).

Recent evidence suggests that the two PPV serotypes show significant differences in their epidemiological properties and in their natural host range $(1,21)$; therefore, control measures may have to be adapted to the particular PPV serotype being targeted. In particular, the $\mathrm{M}$ serotype isolates appear to readily infect peach under field conditions; whereas the D serotype isolates are, in general, much less able to do so. The introduction of PPV-M isolates in France during the mid-1980s and their recent detection in Italy (20), with the ensuing worsening of the PPV situation on the peach crops, is an indication that such isolates have the potential to further deteriorate the PPV situation in many European coun- 
tries. In this respect, the availability of reliable PPV detection and typing assays is the key to continuing efforts to fight the sharka disease in many countries.

In this study, the results of a large-scale trial designed to compare serology-based and nucleic acids-based PPV typing assays are presented. The results obtained indicate that the two types of techniques are, in general, in excellent agreement. However, in a limited number of cases, discrepancies were observed between the various techniques. As a consequence, even if serology-based assays are likely to be preferred for large-scale screening, PCRbased assays should be considered as the reference technique for typing PPV isolates.

\section{MATERIALS AND METHODS}

PPV isolates and preparation of plant samples. Eighty-four PPV isolates from the collections of the Station de Pathologie Végétale (INRA, Bordeaux, France); the Departamento de Protección Vegetal y Biotecnología (IVIA, Valencia, Spain); the Unité de Recherches sur les Arbres Fruitiers et la Vigne (INRA, Bordeaux, France); and the Dipartimento di Protezione delle Piante, Universita degli Studi (Bari, Italy) were used in this study. These isolates were selected to cover both the host range and the geographical range of PPV, in order to give a very broad representation of the virus variability. The viral isolates were maintained under greenhouse conditions either in a woody indicator (GF305 peach seedlings) or in a herbaceous experimental host (Nicotiana benthamiana). Some isolates were also directly analyzed as field samples in their original Prunus host.

Extracts of plant material were prepared by grinding 1:10 (wt/vol) in phosphate-buffered saline, $\mathrm{pH} 7.2(\mathrm{NaCl}, 137 \mathrm{mM}$; KCl, $3 \mathrm{mM}$; $\mathrm{KH}_{2} \mathrm{PO}_{4}, 1.5 \mathrm{mM} ; \mathrm{Na}_{2} \mathrm{HPO}_{4}, 8 \mathrm{mM}$; and sodium azide, $0.02 \%$ ), supplemented with $2 \%$ polyvinylpyrrolidone (PVP K25), $20 \mathrm{mM}$ sodium diethyl dithiocarbamate, and in some instances, $0.5 \mathrm{~g}$ of Tween 20 per liter. The extracts were used in indirect doubleantibody sandwich ELISA assays (ELISA-DASI) or in immunocapture PCR (IC-PCR) (26) assays after a clarification step (10 min of centrifugation, $18.000 \times g$ ). In some cases, the immunocapture phase of IC-PCR was replaced by the printing phase of the printcapture PCR (PC-PCR) technique described by Olmos et al. (19), in which sections of plant material are directly blotted on Whatman 3MM paper (Whatman International, Ltd., Maidstone, England) before PCR.

ELISA-DASI. ELISA-DASI (5) was performed by coating Nunc immunoplates (Nunc, Roskilde, Denmark) with $200 \mu \mathrm{l}$ per well of a solution of $1 \mu \mathrm{g}$ of anti-PPV immunoglobulins from rabbit antiserum per $\mathrm{ml}$ of carbonate buffer. After trapping viral particles from the plant extracts, PPV-D-specific MAbs (MAb 4DG5, $0.1 \mu \mathrm{g} / \mathrm{ml}$, and MAb 4DG11, $0.02 \mu \mathrm{g} / \mathrm{ml}$ ) (4) and PPV-M-specific MAb (MAb Al, ascitic fluid diluted 1/40,000) (2) were then applied. A MAb detecting all PPV isolates (MAb 5B-IVIA, $0.1 \mu \mathrm{g} / \mathrm{ml}$ ) (4) was used to verify the presence of PPV. Following incubation with plant samples, alkaline phosphatase-conjugated goat antimouse immunoglobulins (Sigma Chemical Co., St. Louis, or Boehringer $\mathrm{GmbH}$, Mannheim, Germany) were used. The plates were read at $405 \mathrm{~nm}$ in a Titertek Multiscan Plus MK II automatic reader (Flow Laboratories, McLean, VA). Positive and negative controls (noninoculated GF305 peach seedlings or $N$. benthamiana) were systematically included.

IC-PCR and PC-PCR typing of PPV isolates. One hundred microliters of clarified plant extract was submitted to an immunocapture performed directly in the tubes used for the reverse transcription PCR (RT-PCR) reaction as described previously (26). The coating of the immunocapture tubes was performed using $2 \mu \mathrm{g}$ of immunoglobulins (purified from a rabbit polyclonal antiserum showing broad reactivity towards PPV isolates) per ml. Alternatively, in some cases, the PC-PCR protocol was used, thus avoiding the plant extract preparation and the specific capture phase (19).
The one-step RT-PCR protocol described by Candresse et al. (8) was used. Briefly, $25 \mu$ of RT-PCR mix (10 mM Tris-HCl, pH 8.8; $50 \mathrm{mM} \mathrm{KCl} ; 1.5 \mathrm{mM} \mathrm{MgCl}{ }_{2} ; 0.3 \%$ Triton X-100 (wt/vol); $1 \mu \mathrm{M}$ of each primer; $250 \mu \mathrm{M}$ dNTPs; 0.25 units of avian myeloblastosis virus reverse transcriptase [AMV-RT] [Pharmacia Biotechnology Inc., Uppsala, Sweden]; and 0.5 units of Taq DNA polymerase [Stehelin, Basel, Switzerland]) were directly added to the washed capture tubes. The cDNA synthesis and amplification were carried out in a Biometra Trio-block cycler (Biometra, Göttingen, Germany) at $42^{\circ} \mathrm{C}$ for $45 \mathrm{~min}$, followed by a denaturation phase at $92^{\circ} \mathrm{C}$ for $2 \mathrm{~min}$ and 40 cycles of amplification $\left(92^{\circ} \mathrm{C}\right.$ for $30 \mathrm{~s}, 62^{\circ} \mathrm{C}$ for $30 \mathrm{~s}$, and $72^{\circ} \mathrm{C}$ for $1 \mathrm{~min}$ ). Following amplification, $10 \mu \mathrm{l}$ of PCR products was analyzed by electrophoresis on $1.5 \%$ agarose gels in TBE buffer (Tris, $89 \mathrm{mM}$; boric acid, $89 \mathrm{mM}$; and EDTA, $2 \mathrm{mM}$ ) stained with ethidium bromide and finally visualized under UV light.

Two PCR-based assays were concurrently used to type the PPV isolates. The first assay is based on the detection of the RsaI RFLP discriminating the D and M PPV serotypes (3). The broadreactivity, PPV-specific primers $\mathrm{P} 1$ and $\mathrm{P} 2$ were used to amplify all PPV isolates (28). Following amplification, the PCR fragments were extracted with chloroform, ethanol precipitated and finally digested using the $R s a \mathrm{I}$ restriction endonuclease before gel electrophoresis analysis. The second assay is based on the use of the general P1 primer, together with the PD (5'CTTCAACGACACCCGTACGG3') or PM (5'CTTCAACAACGCCTGTGCGT3') serotype-specific primers. In this case, positive amplification directly detected by gel electrophoresis is only obtained with the pair of primers containing the homologous serotype-specific primer.

Heminested PCR (H-PCR). In some cases, typing using the above described IC-PCR or PC-PCR procedures was replaced by an H-PCR procedure (18), also allowing the direct typing of PPV isolates, but showing increased sensitivity. This assay uses as second-round internal primers the PD and PM serotype-specific primers described above, so that the typing specificity of the two techniques is strictly identical. Amplification products were analyzed as above, except that 3\% agarose gel electrophoresis was used.

Determination and analysis of the nucleotide sequence of PCR-amplified PPV cDNAs. Primers P3D (5'ACATTGCGGAGACAGCACTG3') and P4b (5'TGCCTTCAAACGTGGCACTG3') have been specifically designed to allow the amplification of a region comprising the end of the nuclear inclusion $b$ gene and the hypervariable $\mathrm{N}$-terminal portion of the coat protein gene of PPV isolates belonging to the D serotype. Following amplification using primer pairs $\mathrm{P} 1-\mathrm{P} 2$ or $\mathrm{P} 3 \mathrm{D}-\mathrm{P} 4 \mathrm{~b}$ (using one of the primers in a biotinylated form), the amplified cDNAs were directly sequenced as described by Revers et al. (22). Sequence acquisition and analysis were performed as described (22).

\section{RESULTS AND DISCUSSION}

Serotyping of PPV isolates using MAbs. The names and origins of the 84 PPV isolates analyzed during this work (59 collection isolates and 25 field samples) are presented in Table 1, together with the results obtained using the various typing assays. These isolates originate from a total of 17 countries including all major PPV-affected regions of the world $(17,24)$. The original isolation hosts, although not indicated, cover the biological range of PPV including all major economical hosts of the virus such as apricot ( $P$. armeniaca), European plum ( $P$. domestica), Japanese plum $(P$. salicina), peach and nectarine $(P$. persicae), and sour cherry ( $P$. cerasus, a recently discovered host for some PPV isolates) (15). Thus, it can reasonably be considered that the isolates selected cover both the geographical and biological variability range of PPV. To achieve complete representation of the four groups of PPV isolates, the El Amar isolate (27) and the Sour Cherry isolate (SoC, a member of the PPV-Cherry group) (15) were included in the study, together with members of the D and $M$ serotypes of 
PPV and with the Dideron and Marcus isolates initially described as representative members of these two serotypes (11).

The first observation that can be derived from the analysis of the data presented in Table 1 is that all the PPV isolates tested reacted positively with the 5B-IVIA MAb, thus confirming the excellent polyvalence of this antibody (4). Analysis of the reactivity of the various PPV isolates towards the D-specific MAbs (4DG5 and 4DG11) (4) and the M-specific MAb (AL) (2) indicates that, in the vast majority of isolates for which this information is available (60 out of 67), reactivities towards these serotype-specific reagents are, as expected, mutually exclusive. On the other hand, a perfect correlation (80 out of 80 ) was observed between the reactivities towards the two D-specific MAbs. This result, together with the observation that the optical density values obtained with these two MAbs are always correlated and with preliminary epitope mapping data, provides indirect evi- dence that these MAbs recognize the same epitope or very closely related epitopes.

In only two cases was a simultaneous reaction with both the Dspecific and the M-specific MAbs observed. In the case of isolate AL from Albania, PCR analysis using the serotype-specific primers (8) revealed a mixed infection, since positive amplification was obtained with both the P1-PD and P1-PM primer pairs (Table 1). A similar case of double infection involving $D$ and $M$ serotypes was detected by PCR in isolate X84/P8.1 Bourran. In this case, occurrence of a mixed infection was demonstrated by both serotype-specific PCR and RFLP analysis of a PCR-generated cDNA fragment (3). In the second case, in which simultaneous reaction with the $\mathrm{D}$ - and $\mathrm{M}$-specific serological reagents was observed (Turchia isolate from the INRA-RF collection), PCR analysis only revealed the presence of an M-serotype isolate (discussed below).

TABLE 1. Origin and results of serotyping and polymerase chain reaction (PCR)-based typing for the various plum pox virus (PPV) isolates used in this study

\begin{tabular}{|c|c|c|c|c|c|c|c|c|c|c|}
\hline & & & & \multicolumn{7}{|c|}{ Test $^{\mathrm{e}}$} \\
\hline \multicolumn{4}{|c|}{ PPV isolates } & \multicolumn{4}{|c|}{ ELISA-DASI (MAb) } & \multicolumn{3}{|c|}{ PCR } \\
\hline Name $^{a}$ & $\operatorname{Host}^{b}$ & Origin $^{c}$ & Collection $^{\mathrm{d}}$ & $5 \mathrm{~B}$ & 4DG5 & 4DG11 & $\mathrm{AL}$ & PCR-D & PCR-M & RFLP \\
\hline Dideron & GF305 & France & IVIA & + & + & + & - & + & - & NT \\
\hline *Rouge de Fournès & GF305 & France & INRA-RF 8 & + & - & - & - & + & - & $\mathrm{D}$ \\
\hline C33 Polonais & GF305 & France & INRA-RF 9 & + & + & + & - & + & - & NT \\
\hline Redhaven Orange & GF305 & France & INRA-RF 7 & + & + & + & - & + & - & NT \\
\hline *Colomer Raoux & GF305 & France & INRA-RF 2 & + & - & - & - & + & - & $\mathrm{D}$ \\
\hline Leynaux Eyragues & GF305 & France & INRA-RF 5 & + & + & + & - & + & - & NT \\
\hline Canino Ancian & GF305 & France & INRA-RF 13 & + & - & - & + & - & + & NT \\
\hline A1 & GF305 & France & INRA-RF 14 & + & - & - & + & - & + & NT \\
\hline *X84/P8.1 Bourran & GF305 & France & INRA-RF 15 & + & + & + & NT & + & + & $\mathrm{D}+\mathrm{M}$ \\
\hline SP & GF305 & France & INRA-PV & + & - & - & + & - & + & NT \\
\hline G2 27/43 & GF305 & France & INRA-RF 36 & + & - & - & + & - & + & NT \\
\hline$* 24-4-\mathrm{SE}$ & GF305 & France & IVIA & + & - & - & - & + & - & NT \\
\hline Ms/Mp (Marcus) & GF305 & Greece & IVIA & + & - & - & + & - & + & $\mathrm{M}$ \\
\hline Ms 79 & N. benthamiana & Greece & IVIA & + & - & - & + & - & + & NT \\
\hline Ms 79 Mp & N. benthamiana & Greece & IVIA & + & - & - & + & - & + & NT \\
\hline Ms 89 & N. benthamiana & Greece & IVIA & + & - & - & + & - & + & NT \\
\hline $\mathrm{O}-\mathrm{Gr}$ & GF305 & Greece & IVIA & + & - & - & + & - & + & NT \\
\hline M1A & GF305 & Greece & IVIA & + & - & - & + & - & + & NT \\
\hline Mp5-M & GF305 & Greece & IVIA & + & - & - & + & - & + & NT \\
\hline Sutic Forte & GF305 & Yugoslavia & INRA-RF 18 & + & - & - & + & - & + & NT \\
\hline Sutic Yellow Faible & GF305 & Yugoslavia & INRA-RF 19 & + & + & + & NT & + & - & NT \\
\hline Bela Cvrna \#1 & GF305 & Yugoslavia & INRA-RF 16 & + & - & - & + & - & + & NT \\
\hline SEO & GF305 & Yugoslavia & INRA-RF 20 & + & - & - & + & - & + & NT \\
\hline $\mathrm{W}$ & N. benthamiana & Yugoslavia & IVIA & + & + & + & - & + & - & NT \\
\hline $\mathrm{R} 3$ & N. benthamiana & Yugoslavia & IVIA & + & + & + & - & + & - & NT \\
\hline PS & N. benthamiana & Yugoslavia & IVIA & + & - & - & + & - & + & NT \\
\hline o6 & N. benthamiana & Yugoslavia & IVIA & + & - & - & + & - & + & NT \\
\hline Autumn Giant-Ch & P. salicina-FS & Chile & IVIA & + & + & + & - & + & - & NT \\
\hline $\mathrm{S}^{\text {ta }}$ Rosa-Ch & P. salicina-FS & Chile & IVIA & + & + & + & - & + & - & NT \\
\hline Black Beaut-Ch & $P$. salicina-FS & Chile & IVIA & + & + & + & - & + & - & NT \\
\hline Albar. CB-Ch & P. armeniaca-FS & Chile & IVIA & + & + & + & - & + & NT & NT \\
\hline $\mathrm{AT}$ & $N$. benthamiana & Germany & IVIA & + & + & + & - & + & - & NT \\
\hline NAT & N. benthamiana & Germany & IVIA & + & + & + & - & + & - & NT \\
\hline $\mathrm{SC}$ & N. clevelandii & Germany & IVIA & + & + & + & - & + & NT & NT \\
\hline Prunier Bari & GF305 & Italy & INRA-RF 58 & + & + & + & NT & $\begin{array}{l}+ \\
\text { (con }\end{array}$ & - & $\begin{array}{c}\mathrm{NT} \\
\text { next page) }\end{array}$ \\
\hline
\end{tabular}

${ }^{a}$ The names of the isolates as they appear in their respective collections are given. Isolates for which a discrepancy between the serotyping and PCR-based typing was observed are preceded by an asterisk.

${ }^{\mathrm{b}}$ Host refers to the propagation host used. GF305 $=$ GF305 indicator peach seedling, $N .=$ Nicotiana , and P. $=$ Prunus. When field samples were directly used, this is indicated by the "FS" following the host name.

${ }^{\mathrm{c}}$ Origin refers to the country in which the isolate was originally isolated.

${ }^{\mathrm{d}}$ The collection from which the isolate was obtained is indicated. IVIA = Instituto Valenciano de Investigaciones Agrarias (Valencia, Spain); INRA-RF = Unité de Recherches sur les Arbres Fruitiers et la Vigne of INRA (Bordeaux, France), the code number is also given; INRA-PV = Station de Pathologie Végétale of INRA (Bordeaux, France); and BARI = Dipartimento di Protezione delle Piante, Universita degli Studi (Bari, Italy).

${ }^{\mathrm{e}}$ Results of the various typing assays. + indicates a positive reaction in a particular assay, - a negative reaction, and +/- a weak or erratic reaction. ELISA-DASI $(\mathrm{MAb})$ indicates indirect double-antibody sandwich enzyme-linked immunosorbent assay by monoclonal antibody. PCR-D and PCR-M ref er to direct typing PCR assays using the PD and PM serotype-specific PCR primers either in direct PCR or in print-capture PCR followed by hemineste d-PCR (31 samples), respectively. RFLP indicates restriction fragment length polymorphism analysis of a PCR product obtained using the P1-P2 polyvalent primer pair; the serotype determined in this assay is directly given. NT $=$ not tested.

${ }^{f}$ PPV strain 483 is a recombinant PPV isolate obtained in the laboratory of J. A. García (Madrid, Spain).

${ }^{\mathrm{g}} \mathrm{NA}=$ not applicable 
Failure to react with both types of serotype-specific MAbs was also observed in a few isolates (5 isolates out of 67). In the case of the El Amar (27) and Sour Cherry isolates (16), these results merely reflect the divergent status of these isolates and, in the case of the SoC isolate, confirm previously published results (16). The case of the three other PPV isolates that failed to react with both the Dspecific and the M-specific MAbs (French isolates Rouge de Fournès, Colomer Raoux, and 24-4-SE) is more difficult to interpret, since PCR analysis confirmed the presence of PPV infection (as was predicted by the reactivity towards MAb 5B-IVIA) and demonstrated only the presence of a D serotype isolate (discussed below) by both PCR and RFLP analysis.

It thus appears that although serotyping using the available MAbs is a fairly reliable technique, a few PPV isolates exist that either possess simultaneously the epitopes recognized by these MAbs ( 1 isolate out of 67 ) or do not have any of these epitopes (5 isolates out of 67). Although this could have been expected of widely divergent isolates such as El Amar and SoC, these results are more of a surprise concerning less 'exotic' PPV isolates. They also indicate that serotyping using the available MAbs is not absolutely foolproof.

Typing of PPV isolates using PCR-based assays. Analysis of the typing results obtained using the serotype-specific PCR primers gives, by comparison with the MAb-based typing, a clearer picture; simultaneous amplification using both primer pairs was observed in only 2 cases out of 80 isolates tested. As noted above, these two cases (X84/P8.1 Bourran and AL) reflect a mixed infection involving $\mathrm{D}$ and $\mathrm{M}$ serotype isolates.

Failure to react with both P1-PD and P1-PM serotype-specific primer pairs was also observed in a few cases ( 2 out of 80: isolates Llutxent 11 and Llutxent 145). However, these isolates reacted positively with the P1-P2 primer pair and were shown to be

TABLE 1. (continued from the preceding page)

\begin{tabular}{|c|c|c|c|c|c|c|c|c|c|c|}
\hline & & & & & & & Test $^{\mathrm{e}}$ & & & \\
\hline & PPV isolat & & & & ELISA-1 & ASI MAb & & & PCR & \\
\hline Name $^{a}$ & Host $^{\mathrm{b}}$ & Origin $^{c}$ & Collection $^{\mathrm{d}}$ & $5 \mathrm{~B}$ & 4DG5 & 4DG11 & $\mathrm{AL}$ & PCR-D & PCR-M & RFLP \\
\hline *Turchia & GF305 & Turkey & INRA-RF 59 & + & + & + & + & - & + & M \\
\hline *Abricotier Turquie & GF305 & Turkey & INRA-PV & + & + & + & - & - & + & M \\
\hline SK68 & N. benthamiana & Hungary & IVIA & + & - & - & + & - & + & NT \\
\hline Plovdiv & GF305 & Bulgaria & INRA-RF 21 & + & - & - & + & - & + & NT \\
\hline W-Bel & N. benthamiana & Belgium & IVIA & + & + & + & - & + & - & NT \\
\hline A & N. benthamiana & Czech Rep. & IVIA & + & + & + & - & + & - & NT \\
\hline *AL & N. benthamiana & Albania & BARI & + & + & + & + & + & + & NT \\
\hline$* \mathrm{SoC}$ & P. cerasus & Moldova & INRA-PV & + & - & - & - & $+1-$ & - & M \\
\hline$*$ El Amar & Pisum sativum & Egypt & INRA-PV & + & - & - & - & - & $+/-$ & $\mathrm{M}$ \\
\hline Mariana Nav. & GF305 & Spain & IVIA & + & + & + & - & + & - & NT \\
\hline Mariana Extr. & GF305 & Spain & IVIA & + & + & + & NT & + & - & NT \\
\hline $3.3 \mathrm{RB}$ clo & N. benthamiana & Spain & IVIA & + & + & + & - & + & - & NT \\
\hline $3.4 \mathrm{RB}$ & GF305 & Spain & IVIA & + & + & + & - & + & - & NT \\
\hline $\mathrm{RB} \mathrm{Mp}$ & GF305 & Spain & IVIA & + & + & + & - & + & - & $\mathrm{D}$ \\
\hline 3.3 RB Mp 15 & GF305 & Spain & IVIA & + & + & + & - & + & - & NT \\
\hline 3.3 RB Mp 31 & GF305 & Spain & IVIA & + & + & + & - & + & - & NT \\
\hline $1.20 \mathrm{RR}$ & GF305 & Spain & IVIA & + & + & + & - & + & - & NT \\
\hline 156-JAP & GF305 & Spain & IVIA & + & + & + & - & + & - & NT \\
\hline Pollizo & GF305 & Spain & IVIA & + & + & + & - & + & - & NT \\
\hline *Llutxent 3 & P. salicina-FS & Spain & IVIA & + & - & - & NT & + & - & $\mathrm{D}$ \\
\hline *Llutxent 11 & P. salicina-FS & Spain & IVIA & + & - & - & NT & - & - & D \\
\hline Llutxent 18 & P. salicina-FS & Spain & IVIA & + & + & + & NT & + & - & D \\
\hline Llutxent 25 & P. salicina-FS & Spain & IVIA & + & + & + & NT & + & - & D \\
\hline Llutxent 32 & P. salicina-FS & Spain & IVIA & + & + & + & NT & + & - & D \\
\hline 606 & P. salicina-FS & Spain & IVIA & + & + & + & - & + & - & NT \\
\hline Golden Japan & P. salicina-FS & Spain & IVIA & + & + & + & - & + & - & NT \\
\hline Ojaico & P. armeniaca-FS & Spain & IVIA & + & + & + & - & + & - & NT \\
\hline Canino & P. armeniaca-FS & Spain & IVIA & + & + & + & - & + & - & NT \\
\hline Silver Queen & P. persicae-FS & Spain & IVIA & + & + & NT & - & + & - & NT \\
\hline Armking & P. persicae-FS & Spain & IVIA & + & + & NT & - & + & - & NT \\
\hline $483^{\mathrm{f}}$ & N. benthamiana & Laboratory & IVIA & + & + & + & - & + & - & NT \\
\hline Healthy control $^{\mathrm{g}}$ & P. salicina & NA & NA & - & - & - & - & - & - & NA \\
\hline Healthy controlg & GF305 & NA & NA & - & - & - & - & - & - & NA \\
\hline PCR mix controlg & NA & NA & NA & NA & NA & NA & NA & - & - & NA \\
\hline
\end{tabular}


of the D serotype by RFLP analysis. As these were field isolates, direct re-analysis of the samples could not be performed, which makes interpretation of these results difficult. However, since all Llutxent isolates came from a single experimental plot, the most likely explanation is a failure of the PCR reactions, possibly due to incomplete washing of plant material during the PCR procedure, resulting in inhibition of the PCR reaction (7).

Another interesting result is that, with the exception of these two isolates and of the two divergent El Amar and SoC isolates, a perfect correlation was observed between the direct PCR typing assays and the typing assay based on RFLP analysis. Such results are, however, not surprising, since the serotype-specific primers were designed to anneal to a polymorphic region that contains the $R s a \mathrm{I}$ polymorphism (8). The two divergent isolates cannot be efficiently analyzed using the available serotype-specific PCR primers. Since they do not contain the RsaI site, both isolates type as $\mathrm{M}$ in the RFLP assay. Using the serotype-specific primers, ambiguous and not fully reproducible results are obtained (denoted by $+/-$ signs in Table 1). For example, isolate SoC failed to amplify using the P1-PM primer pair and only weakly amplified (with reproducibility problems) using the P1-PD primer pair. This observation is probably correlated with the presence of mismatches at positions 4, 7, 10, and 13 of the PD primer ( 1 being the 3 -terminal nucleotide) (13). The El Amar isolate shows the reverse situation, since it was not amplified using the P1-PD primer pair and was only weakly amplified using the P1-PM (with mismatches at positions 10 and 13).

Although not completely satisfactory, in particular when it comes to the divergent El Amar and SoC isolates, the PCR-based typing assays give, in general, fewer problems than the serology-based techniques. The RFLP technique provides unambiguous results and readily allows the detection of mixed infections. Similarly, since the PD and PM primers differ at positions 1, 4, 7, 10, and 13 , it is highly unlikely that simultaneous amplification with both sets of primers can be achieved outside of a mixed infection configuration (13), a situation that cannot be readily analyzed using serological reagents.

Comparison of MAb-based and PCR-based typing results. Comparison of the typing results obtained using the MAb- and PCR-based techniques indicates an overall good correlation of the two types of techniques (Tables 1 and 2). This is particularly true if only reactivity towards a specific MAb is retained as an indication of the serotype status of an isolate, as opposed to using also a failure to react as an indication that the particular isolate belongs to the other serotype. Using this restrictive criterion, reactivity towards the D-specific MAbs indicated correctly the presence of a D serotype isolate in $96 \%$ of cases (51 cases out of 53, including two mixed infections) (Table 2). Even better, reactivity towards the M-specific MAb gave a correct indication (presence of an

TABLE 2. Comparison of the results obtained using the serology- and polymerase chain reaction (PCR)-based plum pox virus typing assays

\begin{tabular}{|c|c|c|c|c|}
\hline \multirow[b]{3}{*}{ PCR typing ${ }^{\mathrm{a}}$} & \multicolumn{4}{|c|}{ Serological typing ${ }^{b}$} \\
\hline & \multicolumn{2}{|c|}{ D-specific MAbs } & \multicolumn{2}{|c|}{ M-specific MAb } \\
\hline & + & - & + & - \\
\hline D+ & 49 & 7 & 0 & 43 \\
\hline $\mathrm{M}+$ & 2 & 19 & 20 & 1 \\
\hline $\mathrm{D}+$ and $\mathrm{M}+$ & 2 & 0 & 1 & 0 \\
\hline Other & 0 & Cherry/El Amar & 0 & Cherry/El Amar \\
\hline
\end{tabular}

a PCR typing results are expressed as positive amplification results using the $\mathrm{D}$-specific (D+) or M-specific (M+) typing primers. $\mathrm{D}+$ and $\mathrm{M}+$ indicate samples showing simultaneous amplification using both types of primers. Other indicates isolates showing weak/poorly reproducible PCR amplification results (Cherry and El Amar groups of isolates).

${ }^{\mathrm{b}}$ Serological typing results are expressed as reactivity (noted + ) or absence of reactivity (noted -) towards the D-specific and M-specific monoclonal antibodies (MAbs).
M serotype isolate) in $100 \%$ of cases (including a mixed infection) (Table 2).

Out of the 84 PPV isolates analyzed, a total of 16 showed typing inconsistencies in these experiments (either within or between the two typing techniques) (Table 1). Of these, two cases correspond to mixed infections (X84/P8.1 Bourran and AL) and two to the divergent $\mathrm{El}$ Amar and SoC isolates, leaving 12 samples showing discrepancies. Of those, the seven Llutxent samples, which came from the same $P$. salicina experimental plot, are likely to reflect the presence of a single PPV isolate with unusual characteristics, while the three French samples (Rouge de Fournès, Colomer Raoux, and 24-4-SE), although not originally collected from the same orchard, may correspond to the same outbreak since they were all collected in the same region of France in the early 1980s. This could therefore leave a minimal number of six PPV isolates showing typing discrepancies (one French isolate, Turchia, Abricotier Turquie, and one Llutxent isolate plus El Amar and SoC) out of the total of 84 PPV isolates analyzed. It therefore appears a safe conclusion that PPV isolates behaving differently in the serological and PCR-based assays are a small minority of existing PPV isolates.

In the case of the French and the Llutxent isolates, the discrepancy observed is apparently the result of the absence of the epitope(s) recognized by the D-specific MAbs. Interpretation of these isolates as belonging to the D serotype is based on the following results: (i) positive amplification using the P1-PD primer pair, (ii) typing as D isolates in the RFLP assay, and (iii) positive amplification (in the case of the French isolates) using another pair of serotype-specific primers, P3D-P4b, targeting another region of the genome (data not shown).

Another PPV isolate showing a similar behavior, PPV-94-055, was recently collected from an apricot orchard in southeastern France by J. B. Quiot. PPV-94-055 typed as a PPV-D isolate by both PCR-RFLP and P1-PD positive amplification. On the other hand, similar to the Llutxent isolates or the other French isolates collected in the early 1980s (24-4-SE, Colomer Raoux, and Rouge de Fournès), PPV-94-055 failed to react with either the PPV-Dspecific MAbs (4DG5 and 4DG11) or the PPV-M-specific MAb (AL) (data not shown). The sequence of the N-terminal hypervariable region of the coat protein gene of PPV-94-055 was determined directly from PCR-amplified material as described in the Materials and Methods section. Figure 1A presents a multiple alignment of the PPV-94-055 sequence together with the sequences of other previously sequenced PPV-D and PPV-M isolates obtained from the data banks. Examination of the alignment shows that PPV-94-055 is closely related to the other PPV isolates representative of the D serotype (Rankovic, Skiernevice, and D). Such is confirmed by Figure $1 \mathrm{~B}$, which shows a phylogenetic tree reconstructed from the alignment shown in Figure 1A. From Figure 1 , it is clear that, despite its failure to react with the D-specific MAbs, the PPV-94-055 isolate belongs to the PPV-D cluster. Taken together, these results confirm unambiguously the existence of PPV isolates belonging to the D group or serotype but that have apparently lost the epitope(s) recognized by the PPV D-specific MAbs (4DG5 and 4DG11) available to date.

The case of the other two isolates showing discrepancies (Turchia and Abricotier Turquie) is also interesting. Both of them were isolated in Turkey in peach (Turchia) or in apricot (Abricotier Turquie). Both of these isolates reacted positively with the D-specific monoclonals, while only the Turchia isolate reacted with the M-specific MAb. At the same time, both isolates unambiguously typed as $\mathrm{M}$ serotype members in both the specific primer and RFLP assays. Interpretation of these isolates as belonging to the $\mathrm{M}$ serotype was confirmed by partial sequence analysis on one of them (Abricotier Turquie) (8). These isolates should, therefore, be considered as members of the $M$ serotype possessing the $D$ specific epitope recognized by MAbs 4DG5 and 4DG11. Interestingly, while no isolate of the D serotype reacted with MAb AL, isolate Abricotier Turquie was the only isolate of the M serotype 
tested in this study that did not react with the AL monoclonal, demonstrating that the excellent specificity of this MAb for the M serotype may be faulted in exceptional cases.

It is now clear that neither of the techniques studied here is currently suitable for the typing of the divergent El Amar and SoC PPV isolates. However, availability of the appropriate sequence data $(16,27)$ should render relatively straightforward the selection of PCR primers with the suitable specificity.
Concerning the use of serology-based and PCR-based techniques for the typing of the isolates belonging to the $\mathrm{D}$ and $\mathrm{M}$ serotypes, the results presented here indicate that, even if PCRbased assays seem to be more reliable for the identification of isolates belonging to the $\mathrm{D}$ serotype, both types of techniques show good reliability and should prove useful for the determination of the particular M or D PPV serotype present in infected orchards. The analyses performed here indicate, for example, that

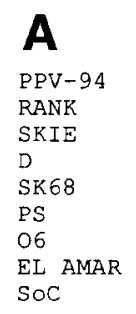

PPV -94
RANK
SKIE
D
SK 68
PS
O6
EL AMAR
SOC

PPV-94

RANK

SKIE

$\mathrm{D}$

SK 68

PS

EL AMAR

SoC

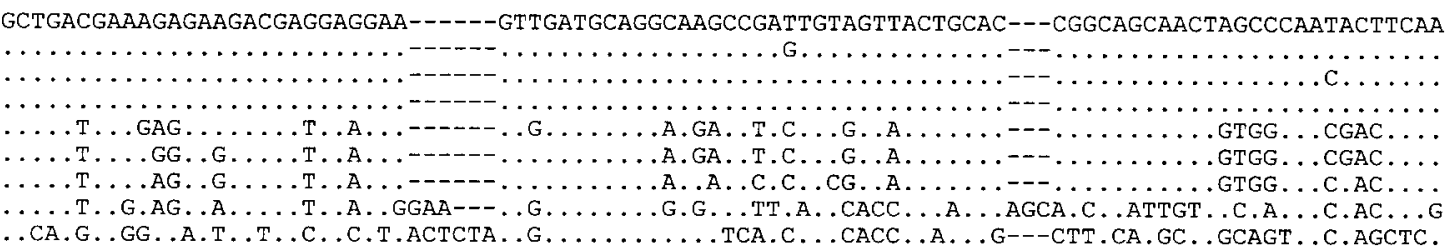

CCACCTCCAGTCATACAGCCTGCA---CCCCGGACTACGGCGCCAATGCTCAACCCCATTTTCACGCCAGCAACAACTCGACCAGCAACAAAACCA

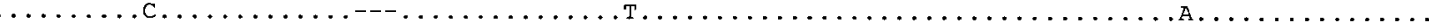

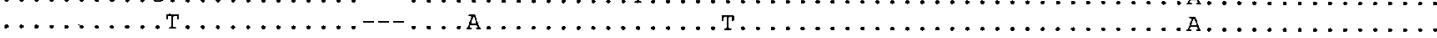

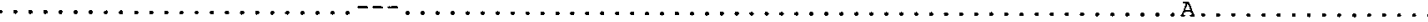

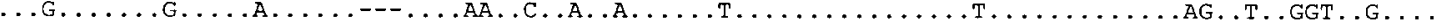

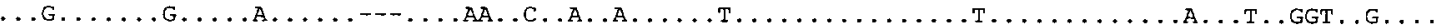

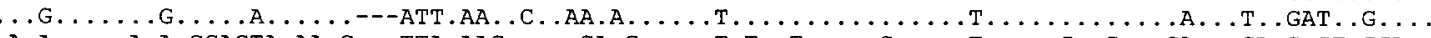

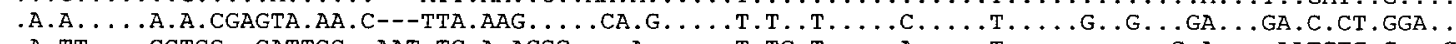

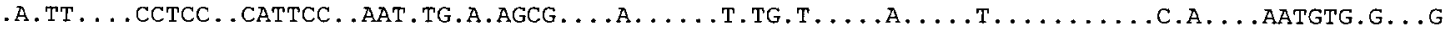

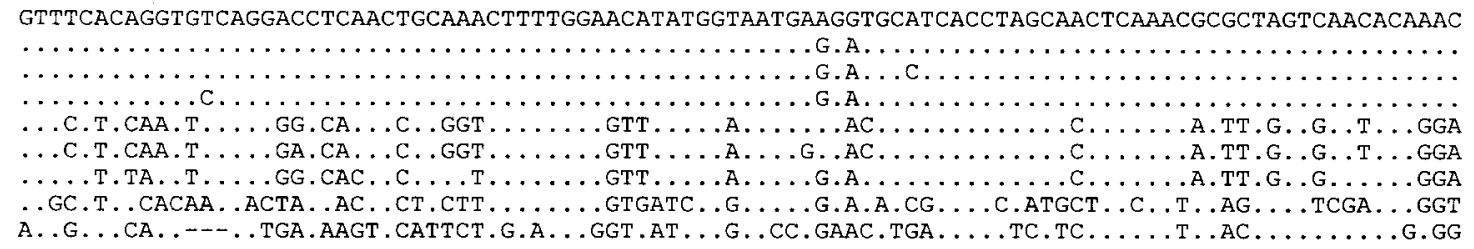

B

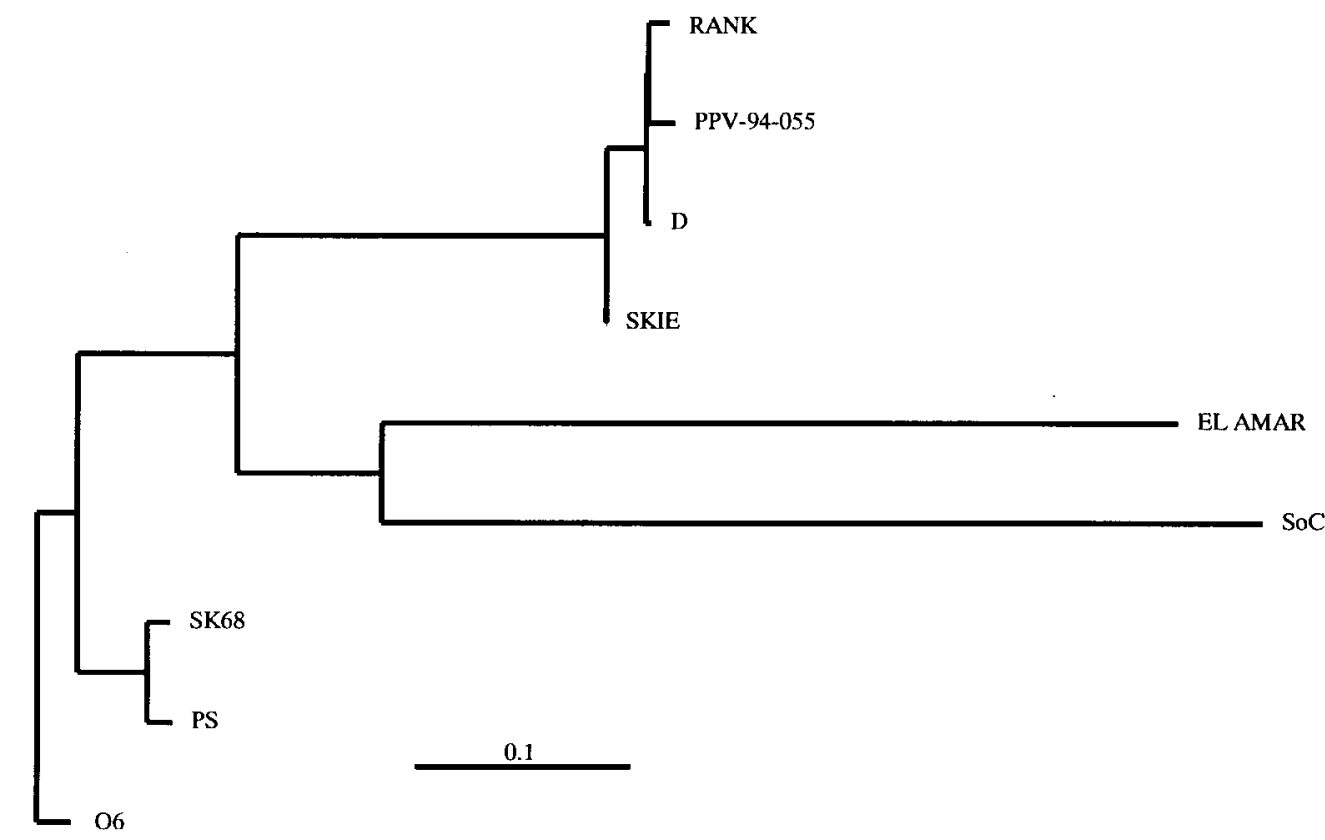

Fig. 1 A, Multiple alignment of the sequence of the N-terminal hypervariable region of the coat protein gene of PPV-94 and of plum pox virus (PPV) isolates belonging to the D, M, El Amar, and Cherry serotypes of PPV. The 276-nt-long region corresponds to nucleotides 8,580 to 8,855 of the PPV-D sequence. Dots indicate nucleotides identical to the PPV-94-055 sequence, dashes indicate gaps inserted in the alignment. The sequences used were retrieved from the data banks and have the following accession numbers. Serotype D of PPV: isolate PPV-94-055 (PPV-94), isolate Rankovic (RANK; M21847), isolate Skiernevice (SKIE; S73776), and isolate D (X16415). Serotype M of PPV: isolate SK68 (X56759), isolate PS (S57405), and isolate o6 (S57404). Serotype El Amar: isolate El Amar (X56258). Serotype Cherry: isolate sour cherry (SoC, X97398). B, Phylogenetic tree reconstructed from the multiple alignment shown on A. The same abbreviations are used as in $\mathbf{A}$. The tree, depicted as a phylogram, was reconstructed as described previously (22). The scale bar indicates the genetic distance in arbitrary units. 
Spain is apparently still free from $\mathrm{M}$ serotype isolates and that no $\mathrm{M}$ serotype isolates were found in the four samples from Chile. Comparison of the two techniques indicates the existence of a few percent of PPV isolates with alterations of the epitopes recognized by the currently available serotype-specific monoclonal reagents. However, their ease of use, lower cost, and overall good performance, especially when using only a positive reaction as the typing criterion, demonstrate that the 4DG5, 4DG11, and AL MAbs will undoubtedly be useful in routine or large-scale screening of PPV infections whenever typing of isolates is requested.

\section{ACKNOWLEDGMENTS}

This work was supported by grants from IMPIVA of the Generalidad Valenciana (89.93/1008), INIA project SC94-035, and an European CAMAR project (CT91-0201). The collaborative INIA-INRA Acción Integrada/INRA-INIA Action Intégrée (PV-2-1995) has been very helpful in facilitating exchanges between the French and Spanish laboratories involved. We thank the many colleagues who contributed PPV isolates either directly or through their collections. We thank E. Camarasa for technical assistance in the serological testing of some isolates. We thank $\mathrm{K}$. Mayo for her help in improving the English of the manuscript.

\section{LITERATURE CITED}

1. Adamolle, C. 1993. Le virus de la Sharka: Obtention et caractérisation partielle d'anticorps polyclonaux spécifiques des protéines non-structurales, approche de la bio-écologie de deux sérotypes épidémiques en verger. Thèse 233. Université de Bordeaux II, Bordeaux, France.

2. Boscia, D., Zeramdini, H., Cambra, M., Potere, O., Gorris, M. T., Myrta, A., Di Terlizzi, B., and Savino, V. 1997. Production and characterization of a monoclonal antibody specific to the M serotype of plum pox potyvirus. Eur. J. Plant Pathol. 103:477-480.

3. Bousalem, M., Candresse, T., Quiot-Douine, L., and Quiot, J. B. 1994. Comparison of three methods for assessing plum pox virus variability: Further evidence for the existence of two major groups of isolates. J. Phytopathol. 142:163-172.

4. Cambra, M., Asensio, M., Gorris, M. T., Pérez, E., Camarasa, E., García, J. A., Moya, J. J., López-Abella, D., Vela, C., and Sanz, A. 1994. Detection of plum pox potyvirus using monoclonal antibodies to structural and non-structural proteins. EPPO (Eur. Mediterr. Plant Prot. Organ.) Bull. 24:569-577.

5. Cambra, M., Camarasa, E., Gorris, M. T., Garnsey, S. M., and Carbonell, E. 1991. Comparison of different immunosorbent assays for citrus tristeza virus (CTV) using CTV-specific monoclonal and polyclonal antibodies. Pages 38-45 in: Proc. Int. Organ. Citrus Virol., 11th. R. H. Brlansky, R. I. Lee, and L. W. Timmer, eds. Int. Organ. Citrus Virol., Riverside, CA

6. Candresse, T., Dosba, F., Quiot, J. B., and Dunez, J. 1993. La Sharka: Le point sur les recherches. Arboric. Fruit. 464:30-35.

7. Candresse, T., Hammond, R., and Hadidi, A. PCR detection of viruses and viroids. In: Control of Plant Virus Diseases. R. K. Khetarpal, H. Koganezawa, and A. Hadidi, eds. The American Phytopathological Society, St. Paul, MN. In press.

8. Candresse, T., Macquaire, G., Lanneau, M., Bousalem, M., QuiotDouine, L., Quiot, J. B., and Dunez, J. 1995. Analysis of plum pox potyvirus variability and development of strain-specific PCR assays. Acta Hortic. 386:357-369.
9. Candresse, T., Macquaire, G., Lanneau, M., Bousalem, M., Wetzel, T., Quiot-Douine, L., Quiot, J. B., and Dunez, J. 1994. Detection of plum pox potyvirus and analysis of its molecular variability using immunocapture-PCR. EPPO (Eur. Mediterr. Plant Prot. Organ.) Bull. 24:585-594.

10. Dunez, R. P., and Sutic, D. 1988. Plum pox virus. Pages 44-46 in: European Handbook of Plant Diseases. I. M. Smith, J. Dunez, R. A. Lelliot, D. H. Phillips, and S. A. Archer, eds. Blackwell Scientific Publications, Oxford, United Kingdom.

11. Kerlan, C., and Dunez, J. 1979. Différenciation biologigue et sérologigue de souches du virus de la sharka. Ann. Phytopathol. 11:241-250.

12. Korschineck, I., Himmler, G., Sagl, R., Steinkellner, H., and Kattinger, H. W. D. 1991. A PCR membrane spot assay for the detection of plum pox virus RNA in bark of infected trees. J. Virol. Methods 31:139-146.

13. Kwok, S., Kellogg, D. E., McKinney, N., Spasic, D., Goda, L., Levenson, C., and Sninsky, J. J. 1990. Effects of primer-template mismatches on the polymerase chain reaction: Human immunodeficiency virus type 1 model studies. Nucleic Acids Res. 18:999-1005.

14. Levy, L., Lee, I. M., and Hadidi, A. 1994. Simple and rapid preparation of infected plant tissue extracts for PCR amplification of virus, viroid and MLO nucleic acids. J. Virol. Methods 49:295-304.

15. Nemchinov, L., and Hadidi, A. 1996. Characterization of the sour cherry strain of plum pox virus. Phytopathology 86:575-580.

16. Nemchinov, L., Hadidi, A., Maiss, E., Cambra, M., Candresse, T., and Damsteegt, V. 1996. Sour cherry strain of plum pox potyvirus (PPV): Molecular and serological evidence for a new subgroup of PPV strains. Phytopathology 86:1215-1221.

17. Nemeth, M. 1994. History and importance of plum pox in stone-fruit production. EPPO (Eur. Mediterr. Plant Prot. Organ.) Bull. 24:525-536.

18. Olmos, A., Cambra, M., Dasí, M. A., Candresse, T., Esteban, O., Gorris, M. T., and Asensio, M. 1998. Simultaneous detection and typing of plum pox potyvirus (PPV) isolates by heminested-PCR and PCR-ELISA. J. Virol. Methods. 68:127-137.

19. Olmos, A., Dasí, M. A., Candresse, T., and Cambra, M. 1996. Printcapture PCR: A simple and highly sensitive method for the detection of plum pox virus (PPV) in plant tissues. Nucleic Acids Res. 24:2192-2193.

20. Poggi Pollini, C., Bissani, R., Giunchedi, L., Gambini, E., and Goio, P. 1996. Sharka: Repermento di un pericoloso ceppo del virus in coltivazioni di pesco. Inf. Agrario 32:77-79.

21. Quiot, J. B., Labonne, G., Boeglin, M., Adamolle, C., Renaud, L. Y., and Candresse, T. 1995. Behaviour of two isolates of plum pox virus inoculated on peach and apricot trees: First results. Acta Hortic. 386:290-295.

22. Revers, F., Lot, H., Souche, S., Le Gall, O., Candresse, T., and Dunez, J. 1997. Biological and molecular variability of lettuce mosaic virus isolates. Phytopathology 87:397-403.

23. Roy, A. S., and Smith, I. M. 1994. Plum pox situation in Europe. EPPO (Eur. Mediterr. Plant Prot. Organ.) Bull. 24:515-523.

24. Smith, I. M., Candresse, T., and Dosba, F. 1994. La Sharka: Ou en est on en Europe et ailleurs? Arboric. Fruit. 471:29-34.

25. Varveri, C., Candresse, T., Cugusi, M., Ravelonandro, M., and Dunez, J. 1988. Use of a ${ }^{32} \mathrm{P}$-labeled transcribed RNA probe for the dot hybridization detection of plum pox virus. Phytopathology 78:1280-1283.

26. Wetzel, T., Candresse, T., Macquaire, G., Ravelonandro, M., and Dunez, J. 1992. A highly sensitive immunocapture polymerase chain reaction method for plum pox potyvirus detection. J. Virol. Methods 39:27-37.

27. Wetzel, T., Candresse, T., Ravelonandro, M., Delbos, R. P., Mazyad, H., Aboul-Ata, E. E., and Dunez, J. 1991. Nucleotide sequence of the 3'terminal region of the RNA of the El Amar strain of plum pox potyvirus. J. Gen. Virol. 72:1741-1746.

28. Wetzel, T., Candresse, T., Ravelonandro, M., and Dunez, J. 1991. A polymerase chain reaction assay adapted to plum pox potyvirus detection. J. Virol. Methods 33:355-365. 